\title{
Hunting pressure is a key contributor to the impending extinction of Bornean wild cattle
}

\author{
Penny C. Gardner ${ }^{1,2,3,4}$, Benoît Goossens ${ }^{1,2,5,6, *}$, Soffian Bin Abu Bakar ${ }^{5}$, \\ Michael W. Bruford ${ }^{2,6}$
}

\begin{abstract}
${ }^{1}$ Danau Girang Field Centre, c/o Sabah Wildlife Department, Wisma Muis, 88100 Kota Kinabalu, Sabah, Malaysia ${ }^{2}$ Organisms and Environment Division, Cardiff School of Biosciences, Cardiff University, Sir Martin Evans Building, Museum Avenue, Cardiff CF10 3AX, UK

${ }^{3}$ School of Biological Sciences, Faculty of Environmental and Life Sciences, Life Sciences Building 85, University of Southampton, Highfield Campus, Southampton SO17 1BJ, UK
\end{abstract}

${ }^{4}$ RSPB Centre for Conservation Science, The Royal Society for the Protection of Birds, The Lodge, Sandy SG19 2DL, UK

${ }^{5}$ Sabah Wildlife Department, Wisma Muis, 88100 Kota Kinabalu, Sabah, Malaysia

${ }^{6}$ Sustainable Places Research Institute, Cardiff University, 33 Park Place, Cardiff CF10 3BA, UK

\begin{abstract}
Widespread and unregulated hunting of ungulates in Southeast Asia is resulting in population declines and localised extinctions. Increased access to previously remote tropical forest following logging and changes in land-use facilitates hunting of elusive wild cattle in Borneo, which preferentially select secluded habitat. We collated the first population parameters for the Endangered Bornean banteng Bos javanicus lowi and developed population models to simulate the effect of different hunting offtake rates on survival and the recovery of the population using reintroduced captive-bred individuals. Our findings suggest that the banteng population in Sabah is geographically divided into 4 management units based on connectivity: the Northeast, Sipitang (West), Central and Southeast, which all require active management to prevent further population decline and local extinction. With only $1 \%$ offtake, population growth ceased in the Northeast and Sipitang. In the Southeast and Central units, growth ceased at 2 and $4 \%$ offtake, respectively. Extinction was estimated at 21-39 yr when offtake was 5\%, occurring first in Sipitang and last in the Central unit. Supplementing the population with captive-bred individuals suggested that inbreeding was likely to limit population growth if using $\leq 20$ founder individuals. Translocating 2 individuals for a $10 \mathrm{yr}$ period, starting after $20 \mathrm{yr}$ of captive breeding resulted in a faster population recovery over $100 \mathrm{yr}$ and a lower extinction probability. Our results suggest that shielding the population against further losses from hunting will be key to their survival in the wild, provided that active management in the form of captive breeding is developed in the interim.
\end{abstract}

KEY WORDS: Banteng $\cdot$ Bos javanicus lowi $\cdot$ Hunting $\cdot$ Offtake $\cdot$ Population modelling $\cdot$ Vortex Tropical forest $\cdot$ Borneo

\section{INTRODUCTION}

Unsustainable hunting of wild animals for human consumption is an acute problem in Southeast Asia, where the impacts are exacerbated by globally unmatched rates of deforestation (Dobson et al. 2019). While there is increasing evidence that widespread

\footnotetext{
${ }^{*}$ Corresponding author: GoossensBR@cardiff.ac.uk
}

and intensive hunting across the tropics has resulted in defaunation, the true extent of over-hunting and its specific impacts upon animal communities are poorly understood (Tilker et al. 2019). Ungulates often suffer widespread population declines, which are largely due to the increased pressures of agricultural development and expansion of concession land, 
habitat encroachment and unregulated hunting (Steinmetz et al. 2010, Melletti \& Burton 2014).

In Borneo, strong evidence suggests that hunting for ungulates has always been prevalent and was commonplace in prehistoric indigenous communities (Chazine 2005, Aubert et al. 2018), providing a major source of protein (Bennett et al. 2000). Today, however, hunting in Borneo is conducted by urban and rural communities for different purposes and using more sophisticated methods, and has likely reached unsustainable levels for the endangered Bornean banteng Bos javanicus lowi. Differences in motivation for hunting are known to exist, and the general methods employed are discussed at length by Harrison et al. (2016). The motivations for specifically targeting wild cattle appear to vary, ranging from subsistence hunting by locals and forest contractors for personal consumption, gifting of whole carcasses for celebrations and festivals, sport hunting, and acquiring trophies for personal status or trade for medicinal properties (Harrison et al. 2016). Furthermore, Bornean banteng graze on crop plants in the grasslands of East Kalimantan (Indonesian Borneo) and are therefore perceived as a pest species and hunted (Hedges \& Meijaard 1999). Firearms and dogs have been the commonly used methods since the early 20th century (Rutter 1922), but the prospects of hunting success have dramatically improved given the provision of semi-automatic weapons and firearm sights, together with off-road vehicles, excavators used in timber extraction, boats and motorbikes. Bornean bantengs are also caught in snares, enduring major injuries such as hoof dismemberment as a consequence of single-strand snares set at ground level along trails and abandoned logging roads in the forest (Gardner et al. 2019).

Over the past 3 decades, a declining trend in Bornean bantengs has been described (Davies \& Payne 1982, Boonratana 1997, Hedges \& Meijaard 1999, Olsen 2003). Localised extinctions have occurred in Sabah (Malaysian Borneo) (Melletti \& Burton 2014), in areas where previously remote forest was opened up by timber harvesting. First-hand reports from logging contractors in the West, Central and
Northeast regions of Sabah describe sourcing of wild cattle bushmeat for logging camps during the 1980s and 1990s, thus reducing, and in some cases, completely eradicating, any remaining individuals. In years following the extraction of timber, the access provided by abandoned logging roads has also almost certainly increased hunting pressure (Kleinschroth \& Healey 2017).

The Bornean banteng is a 'totally protected' species and listed under Schedule 1 of the Sabah Wildlife Enactment 1997 due to its small population size, currently estimated at 326 individuals (Sabah Wildlife Department 2019). Poaching of Bornean bantengs in Sabah is therefore not permitted (Sabah Wildlife Department 2019). Evidence of banteng poaching is challenging to obtain; it is seldom reported to the authorities, and the majority of incidences surface primarily via social media (Fig. 1) and are occasionally covered by local newspapers (Sario 2015, Sarda 2016). Major losses have been sustained over recent years, but the majority remain undocu-
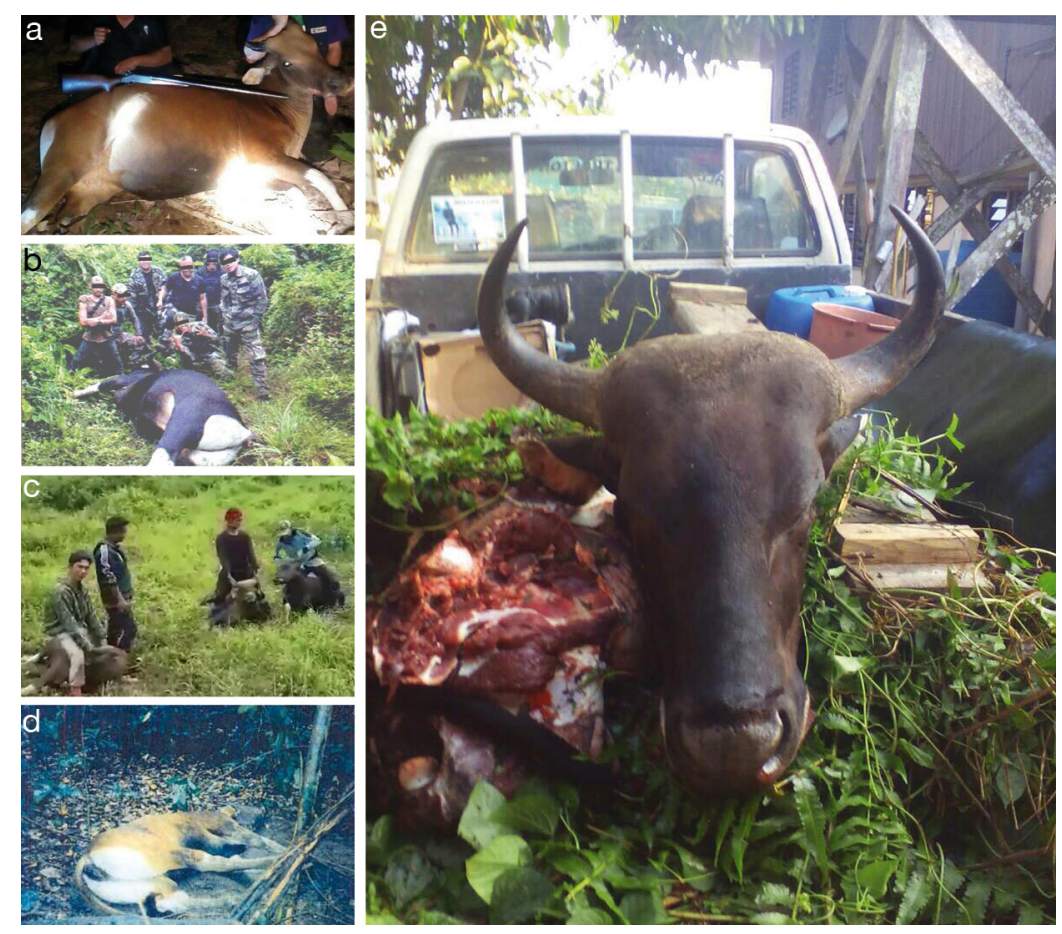

Fig. 1. (a) A cow shot in 2017 in the region surrounding the Maliau Basin Conservation Area. Photo obtained from an anonymous source. (b) A group of hunters with a bull shot in 2015 inside a protected forest, either Tabin or Ulu Segama Forest Reserve. Photo from a newspaper article by the (Sabah) Daily Express on 28/01/2016. (c) A still captured from a video of a group of hunters who had shot 3 juvenile bulls in 2018 in what is thought to be Paitan Forest Reserve. Video obtained from an anonymous source. (d) A juvenile cow caught in a snare in an unknown location in Sabah (Olsen 2002). (e) A mature bull shot in Tabin Wildlife Reserve in 2017 and concealed by leaves in the back of a pickup truck. Photo from an anonymous source 
mented and with insufficient evidence or resources to bring about prosecutions. Losses are largely evidenced by photographs of hunters with their trophy, and trophy heads on display in rural houses (Hedges \& Meijaard 1999). Recent known cases of poaching communicated through social media have documented the loss of 4 individuals in 2017, and 3 bulls in 2018, both within Sabah (B. Goossens pers. obs.). However, the number of reported cases is thought to be unrepresentative of the actual number of sustained deaths, but regular offtake is likely to be unsustainable for this species that already exists at an extremely low density in Borneo owing to recent threats.

Studies of wild bantengs are relatively infrequent; the most widely documented subspecies are $B . j$. birmanicus in the Eastern Plains of Cambodia (Gray \& Phan 2011, Gray et al. 2011, 2012, Gray 2012, Pin et al. 2020), B. j. javanicus in Java (Pudyatmoko \& Djuwantoko 2006, IUCN-SSC Asian Wild Cattle Specialist Group 2010, Pudyatmoko 2017), and a feral population of $B$. javanicus, presumed to be $B . j$. javanicus because of their Balinese origins (see Bradshaw et al. 2006), in northern Australia (Choquent 1993, Bradshaw et al. 2007). In contrast, with limited baseline data available on the demography of Bornean bantengs and large gaps in our understanding concerning the impacts of hunting, planning optimal conservation procedures and measuring the effectiveness of mitigation strategies is extremely difficult. This study therefore aimed to collate the first set of biological parameters for the Bornean banteng and banteng per se (B. javanicus) using data from studbooks, published research and circumstantial data, and combined with anecdotal information on hunting prevalence. Population models were developed and parameterised using this new compilation of biological data to simulate the survival of Bornean bantengs in Sabah given differing scenarios of offtake from hunting, and the recovery of the population by supplementing herds with reintroduced individuals bred in in situ captivity.

\section{MATERIALS AND METHODS}

Given the relative paucity of information on the intrinsic (biological) and extrinsic (environmental) factors influencing the population biology of the banteng species in general and the endemic Bornean banteng in Sabah in particular, a number of approaches were taken to maximise the reliability of the modelling that was undertaken. First, the IUCN Spe- cies Survival Commission (SSC) Asian Wild Cattle Specialist Group (AWCSG) collated all available information for all currently recognised subspecies of banteng (Bos javanicus lowi, B. j. javanicus and $B$. j. birmanicus) and for the species as a whole (B. javanicus) where the subspecies designation could not be attributed. Literature was identified through communications with members of the AWCSG, from the IUCN Red List Banteng species account, Chester Zoo, Copenhagen Zoo, San Diego Zoo, Houston Zoo, the Sabah Wildlife Department, the Sabah Forestry Department and local printed newspapers. Data sources included the European and American studbook databases, direct observations recorded in the wild during field work, circumstantial information from stakeholders involved in species and forest management, newspaper articles and social media messages detailing hunting incidents of bantengs, and published literature available through scientific search engines (Scopus, Web of Science and Google Scholar). This information was used to develop the baseline model for the species (further details available from the authors upon request; key baseline parameters are summarised in Table 1). Second, a general protocol was adopted that would enable the model to be developed in a structured way, minimising unnecessary complexity, starting with (1) developing a baseline model focussing on the intrinsic biological parameters that were obtained from literature and field research, and were agreed in a stakeholder consultation process; followed by (2) using the intrinsic rate of growth from the above model to test whether the baseline model was parameterised realistically, followed by sensitivity testing of those parameters that were less certain to refine the model; (3) configuring a metapopulation model based on current estimates from forest areas known to contain bantengs, including an appreciation of the connectivity among these areas or lack thereof; (4) modelling a variety of harvesting offtake rates at $1,2,3,4$ and $5 \%$ of the starting population size for all populations that were based on recent poaching events in Sabah, to assess how different hunting rates affect population viability; and (5) evaluating management interventions including the cessation of hunting, the establishment of a captive population and its early use in population augmentation, and the connection of 2 isolated subpopulations in Eastern Sabah.

Following the agreement of the baseline model during the consultation process, a population-specific model was initiated, initially comprising 5 subpopulations across Sabah, namely Sipitang, Southeast, Central-south, Central-north and Northeast regions 
Table 1. Population parameters for 3 banteng subspecies that were collated from various sources, including studbooks, observations in the wild and the literature, and were used for modelling the survival of Bornean banteng in Sabah, Malaysia. AWCSG: Asian Wild Cattle Specialist Group

\begin{tabular}{|c|c|c|}
\hline Parameter & Model value(s) & Justification \\
\hline Number of years modelled & 100 & Approximately 10 generations \\
\hline $\begin{array}{l}\text { Correlation between reproduction } \\
\text { and survival as a function of } \\
\text { environmental variance }\end{array}$ & 0.2 & $\begin{array}{l}\text { Unknown but expected to be relatively } \\
\text { low due to } K \text {-selected nature of the species (i.e. low years } \\
\text { for reproduction are not always low years for survival) }\end{array}$ \\
\hline Reproductive system & $\begin{array}{l}\text { Short-term } \\
\text { polygyny }\end{array}$ & $\begin{array}{l}\text { Molecular analysis of feral banteng in Australia } \\
\text { (Bradshaw et al. 2007) }\end{array}$ \\
\hline Age $(y r)$ of first offspring - females & 3 & Gardner et al. (unpubl.) \\
\hline Age $(\mathrm{yr})$ of first offspring - males & 3 & Gardner et al. (unpubl.) \\
\hline Max age (yr) female reproduction & 18 & North American Region Banteng studbook \\
\hline Max age (yr) male reproduction & 19 & North American Region Banteng studbook \\
\hline Max lifespan (yr) & 30 & Unknown but thought to be $25+$ \\
\hline Max number of calving events per year & 1 & AWCSG \\
\hline $\begin{array}{l}\text { Max number of offspring per } \\
\text { calving event }\end{array}$ & 2 & $\begin{array}{l}\text { AWCSG from Bos javanicus javanicus (twinning frequency } \\
0.012 \text { ) }\end{array}$ \\
\hline Sex ratio at birth & $50: 50$ & No other data \\
\hline Density dependence & No & Intrinsic model \\
\hline $\begin{array}{l}\% \text { adult females breeding per year } \\
\quad \text { (interbirth interval) }\end{array}$ & $\begin{array}{c}15.8,25 \\
35,40,50\end{array}$ & $\begin{array}{l}\text { Lower bound estimated from North American Region Banteng } \\
\text { studbook, values tested up to } 1 \text { offspring every } 2 \text { yr (most com- } \\
\text { monly reported value for wild Bos species, including banteng) }\end{array}$ \\
\hline$\%$ Female mortality \pm SD & $\begin{aligned} 20 & \pm 10(\text { Age } 0-1) \\
2 & \pm 5(\text { Age } 1-2) ; \\
4 & \pm 5(\text { Age } 2-3) ; \\
11.9 & \pm 2(\text { Age } 3+)\end{aligned}$ & $\begin{array}{l}\text { For subadults, AWCSG data from } B . j \text {. javanicus. For } \\
\text { adults, estimated from the North American Region Banteng } \\
\text { studbook (both sexes) - equates to a max lifespan of } \sim 28 \mathrm{yr}\end{array}$ \\
\hline$\%$ Male mortality $\pm \mathrm{SD}$ & $\begin{aligned} 26 & \pm 10(\text { Age } 0-1) \\
8 & \pm 5(\text { Age } 1-2) \\
4 & \pm 5(\text { Age } 2-3) \\
11.9 & \pm 2(\text { Age } 3+)\end{aligned}$ & $\begin{array}{l}\text { For subadults, AWCSG data from } B . j \text {. javanicus. For adults, } \\
\text { estimated from the North American Region Banteng studbook } \\
\text { (both sexes) - equates to a max lifespan of } \sim 28 \mathrm{yr}\end{array}$ \\
\hline Catastrophes & None & Intrinsic model \\
\hline $\begin{array}{l}\% \text { males in breeding pool } \\
\text { (can potentially breed) }\end{array}$ & 100 & No additional data to start with \\
\hline Initial population size (n) & 326 & AWCSG — current best estimate for Sabah \\
\hline Carrying capacity & 10000 & Set as effectively infinite (so as not to limit population growth) \\
\hline
\end{tabular}

(Fig. 2). Population estimates were provided by the AWCSG, and carrying capacity was estimated for each region based on (1) a mean density estimate of 0.66 ind. $\mathrm{km}^{-2}$ for intact forest and 0.33 ind. $\mathrm{km}^{-2}$ for disturbed forest, and (2) values extracted from IUCN data using density estimates for relatively undisturbed forests in mainland Asia, specifically Cambodia, where it is estimated that in excess of 1000 banteng existed across $15000 \mathrm{~km}^{2}$ prior to 1960 (Gray et al. 2011), but accounting for an estimated $90 \%$ population decline as a result of uncontrolled hunting (Gardner et al. 2016). Preliminary density estimates in Sabah are much lower and range between 0.61 and 0.95 (95\% CI: 0.32-1.66) individuals per $100 \mathrm{~km}^{2}$ for Tabin Wildlife Reserve and between 0.55 and 0.56 (0.21-2.09) for Malua Forest Reserve, based on natural marks using a spatially explicit capturerecapture framework (Gardner et al. 2019). Validation of the parameters used in the modelling was conducted through consultation with experts at the first banteng population viability working group meeting held on 27 November 2017 in Kota Kinabalu, Sabah (Malaysian Borneo) prior to modelling. Revisions to some model parameters were made during consultation with experts at the population viability working group, hereafter referred to as the PHVA group (Table 2).

A number of banteng poaching events have recently been recorded, and it is estimated that $70 \%$ or more go unrecorded (PHVA group). Recent known hunting events of banteng in Sabah (12 individuals killed between January 2017 and December 2017, 


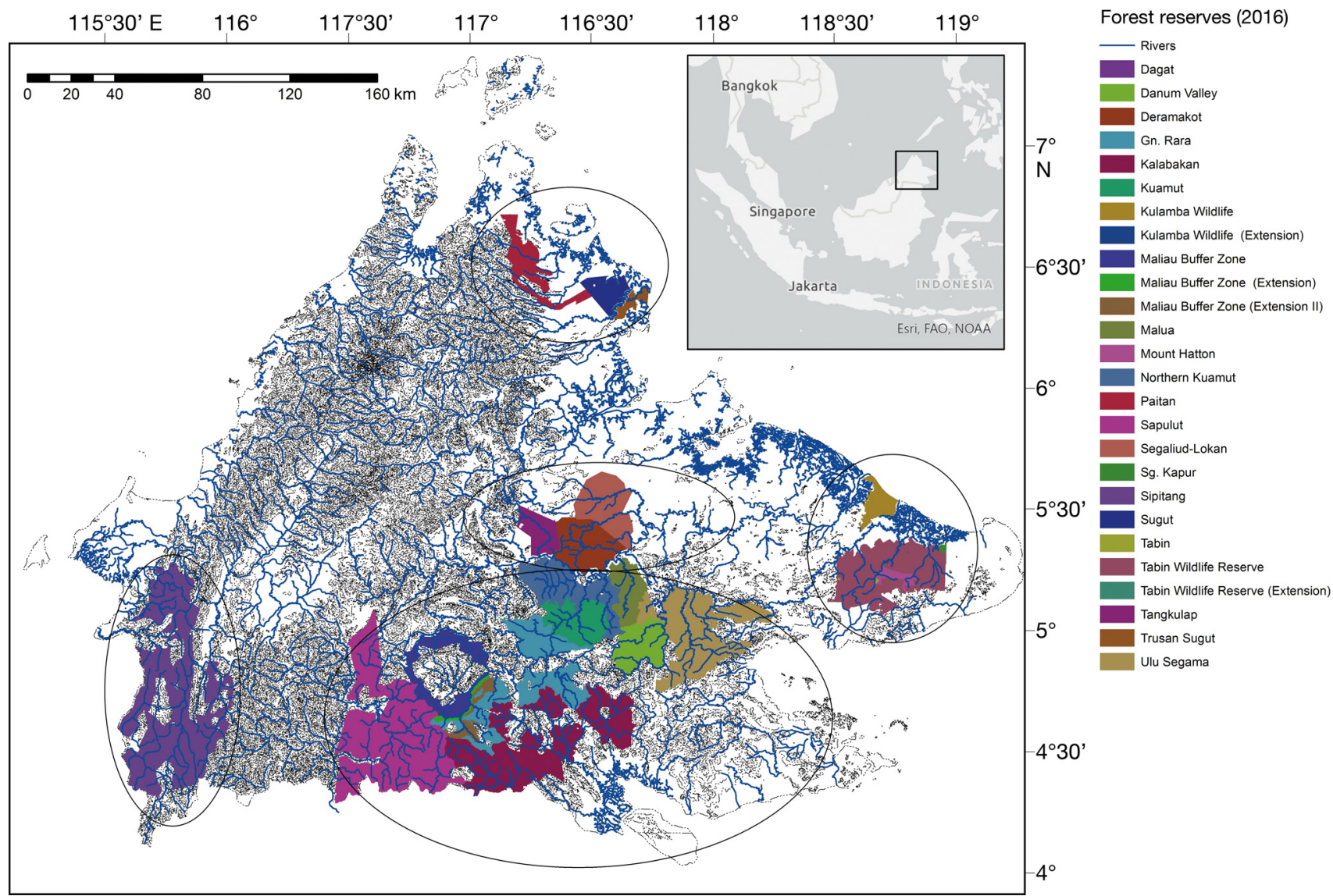

Fig. 2. The 5 sub-populations of Bornean banteng (ellipses) used for population viability modelling, located in the northern Malaysian state of Sabah, Borneo. The map was generated using ArcGIS® software version 10.1 (ESRI), with data from Natural Earth and the Sabah Forestry Department

Table 2. Revised model parameters established during consultation with experts at a working group meeting held in Kota Kinabalu, Sabah (Malaysian Borneo), on 27 November 2017. PHVA: Population and Habitat Viability Assessment

\begin{tabular}{|lcl|}
\hline Parameter & Model value(s) & Justification \\
\hline Inbreeding depression? & Yes & Relevant for smaller populations \\
Age (yr) of first offspring males & 5 & PHVA \\
Max age (yr) female reproduction & 16 & PHVA \\
Max age (yr) male reproduction & 16 & PHVA \\
Max lifespan (yr) & 20 & PHVA — lifespan shorter in the wild than in captivity \\
Max number of offspring per & 1 & PHVA — can ignore very rare twinning events \\
$\quad$ calving event & 20 & PHVA - bachelor groups are common and harems comprise \\
\% males in breeding pool & & 1 adult male to 5 adult females \\
(can potentially breed) & & \\
\hline
\end{tabular}

B. Goossens pers. obs.) indicates that approximately $4 \%$ of the total Sabah population may be poached annually at the present time. Several harvest models were developed to examine offtake rates at 1, 2, 3, 4 and $5 \%$ of the starting population size for all populations. Additional models were proposed in order to examine the combined effect of sustained offtake with catastrophic poaching events (mass killings), but these were not pursued because they could not be reliably quantified.

Further modelling was carried out, first to model the establishment of a captive population as a resource for future translocations in the wild. This was founded with 20 individuals (including 15 individuals 
from the Northeast population if they need to be protected in a captive environment), and from which 1 male and 1 female are translocated into the wild over a 10 yr period, starting at Year 10 and Year 20.

All population modelling was carried out using Vortex v10 (Lacy \& Pollak 2017). Key literature used to guide this process was Lacy et al. (2015). Sensitivity testing based on the percentage of females breeding per year was carried out using parameters from Table 1 and 1000 simulations.

\section{RESULTS}

\subsection{Development of a baseline model}

Owing to shortages of biological data and the supplementation of population parameters from other banteng subspecies, our model parameters were not considered exclusive to Bos javanicus lowi and lack extrinsic parameterisation. Sensitivity testing based on a higher number of females breeding per year (50\%) with 1000 simulations yielded an intrinsic growth rate of $4.3 \pm 5.7 \%$ (SD). The results of this simulation can be found in Fig. 3.

\subsection{Population model}

The estimated population-specific parameters comprised population size, carrying capacity $(K)$ and its trend, and can be found in Table 3. For the 5-population model, the carrying capacity for Sipitang (estimated current population size, $\mathrm{n}=33$ ) was initially

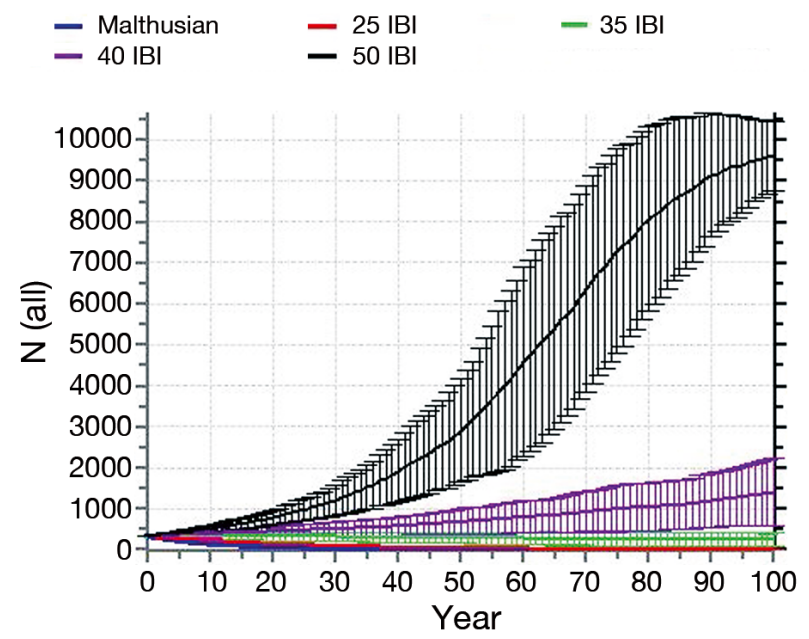

Fig. 3. Population size response $( \pm \mathrm{SD})$ in the baseline model varying the $\%$ of females breeding each year (interbirth inter-

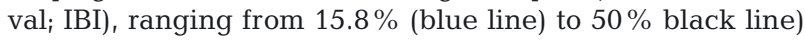

estimated at 826 but revised to 301 because past and current management practices have reduced suitable habitat, including natural forest management $(36.4 \%)$ and intensive tree plantations (ITPs) that are clear-felled on rotation $(63.6 \%)$. We excluded ITPs from carrying capacity estimates given the importance of natural forest cover, primarily tropical lowland dipterocarp forest, as key banteng habitat in Sabah, which was modelled by Lim et al. (2021). In other regions, the population size and carrying capacity were $\mathrm{n}=52$ (later revised to 82) and $K=872$ for the Southeast (Tabin, Kulamba); $\mathrm{n}=35, K=267$ for the Northeast (Paitan, Sugut); $\mathrm{n}=121, K=3642$ for the Central-south (Maliau, Segama, Malua, Sapulut); and $\mathrm{n}=85, K=551$ for the Central-north (Deramakot, Segaliud-Lokan, Tangkulap). Following the initial estimation of $K$ for Sapulut within the Centralsouth unit, further revision was also made given the history of extensive logging over the past $35 \mathrm{yr}$; the proportions of forest that may, in reality, provide suitable habitat for bantengs are smaller than the total area (4\% conservation, $61 \%$ natural forest management in 2009). The carrying capacity is probably circa 497, reducing the Central-south to $K=3374$.

Given the estimated small population sizes, inbreeding depression was modelled for all populations using the default vertebrate values in Vortex in the absence of other data (6.29 lethal equivalents and $50 \%$ of inbreeding depression due to recessive lethal alleles). The results of the first population-based simulation yielded growth rates varying between 0.011 (Sipitang) and 0.034 (Central-south), and only Sipitang and Northeast yielded any simulations trending to extinction ( 1 and $8 \%$, respectively). The population-based model was then revised to (1) increase the population size estimate for the Southeast population to 82 (including the value from Kulamba) and to (2) amalgamate the central populations because animals can and have been observed dispersing (river crossing) between the 2 units (PHVA group). At the same time, the Central-south population estimate was revised upwards to 170 to account for individuals that may have existed in locations that were not surveyed, yielding a total central population estimate of 255 individuals.

\subsection{Hunting}

Fig. 4 shows the extinction impact of 3,4 and $5 \%$ hunting over a $40 \mathrm{yr}$ period in all subpopulations. A $3 \%$ offtake resulted in high extinction probabilities in all subpopulations except Central over a $40 \mathrm{yr}$ 
Table 3. Population and carrying capacity estimates for Bornean banteng in Sabah used in population viability modelling. $K$ : carrying capacity (based on a mean density estimates of 0.66 and 0.33 ind. $\mathrm{km}^{-2}$ for intact and disturbed forests, respectively). Good/intact: percentage of intact habitat. na: parameters were not estimated for this location. Blanks in $\mathrm{N}$ column indicate unknown values

\begin{tabular}{|c|c|c|c|c|c|c|}
\hline Reserve & $\begin{array}{l}\text { Forest } \\
\text { class }\end{array}$ & Notes & $\begin{array}{c}\text { Area }\left(\mathrm{km}^{2}\right) \\
\text { of suitable } \\
\text { habitat }\end{array}$ & $\begin{array}{c}\text { Good/ } \\
\text { intact } \\
(\%)\end{array}$ & $\begin{array}{c}K \\
\left(\mathrm{~km}^{2} \times 0.66\right. \\
\text { or } 0.33)\end{array}$ & $\begin{array}{c}\mathrm{N} \\
\text { actual }\end{array}$ \\
\hline Maliau Buffer Zone (Extension) & 1 & Forest class 1 (Protection & 51.77 & $70-100$ & 34 & \\
\hline Maliau Buffer Zone & 1 & Forest): forest conserved for & 466.39 & & 307 & \\
\hline Ulu Segama & 1 & the protection of watershed & 1271.16 & & 838 & \\
\hline $\begin{array}{l}\text { Maliau Buffer Zone } \\
\text { (Extension II) }\end{array}$ & 1 & $\begin{array}{l}\text { and stability of soil, water } \\
\text { conservation, and other }\end{array}$ & 138.02 & & 91 & 40 \\
\hline Malua Forest Reserve & 1 & environmental factors. & 339.31 & & 223 & 36 \\
\hline Tangkulap Forest Reserve & 1 & Logging is not permitted & 272.75 & & 180 & 17 \\
\hline Trusan Sugut Forest Reserve & 1 & in these areas. & 86.49 & & 57 & \\
\hline Sugut Wildlife Corridor & 1 & & 2.97 & & na & \\
\hline Gn. Rara Forest Reserve & 2 & Forest class 2 (Commercial & 1212.17 & $50-70$ & 400 & \\
\hline Kalabakan Forest Reserve & 2 & Forest): forest allocated for & 1819.72 & & 600 & \\
\hline Kuamut Forest Reserve & 2 & harvesting to supply & 1163.71 & & 384 & 30 \\
\hline Segaliud-Lokan Forest Reserve & 2 & timber and other & 572.83 & & 189 & 46 \\
\hline Deramakot Forest Reserve & 2 & produce contributing & 550.57 & & 182 & 22 \\
\hline Sapulut Forest Reserve & 2 & to the state's economy. & 1506.11 & & 497 & 15 \\
\hline Paitan Forest Reserve & 2 & Harvesting carried out & 417.36 & & 138 & 18 \\
\hline Sipitang Forest Reserve & 2 & using sustainable forest & 911.60 & & 110 & 33 \\
\hline Sugut Forest Reserve & 2 & management principles. & 232.71 & & 77 & 15 \\
\hline Tabin Forest Reserve & 6 & Forest class 6 (Virgin Jungle): & 4.08 & $70-100$ & na & \\
\hline Dagat Forest Reserve & 6 & forest conserved intact strictly & 1.62 & & na & \\
\hline Mamahat Forest Reserve & 6 & for forestry research including & 0.78 & & na & \\
\hline Sg. Kapur Forest Reserve & 6 & $\begin{array}{c}\text { biodiversity and genetic } \\
\text { conservation. Logging strictly } \\
\text { prohibited. }\end{array}$ & 12.33 & & na & \\
\hline Tabin Wildlife Reserve & 7 & Forest class 7 (Wildlife & 1117.92 & $70-100$ & 738 & 52 \\
\hline $\begin{array}{l}\text { Tabin Wildlife Reserve } \\
\text { (Extension) }\end{array}$ & 7 & $\begin{array}{l}\text { Reserves): Forest conserved } \\
\text { primarily for the }\end{array}$ & 2.65 & & na & \\
\hline Kulamba Wildlife Sanctuary & 7 & protection and & 203.39 & & 134 & \\
\hline $\begin{array}{l}\text { Kulamba Wildlife Sanctuary } \\
\text { (Extension) }\end{array}$ & 7 & $\begin{array}{l}\text { conservation of wildlife. } \\
\text { Logging prohibited. }\end{array}$ & 2.14 & & na & \\
\hline
\end{tabular}

period, and $5 \%$ offtake had catastrophic consequences with no population having a probability of survival exceeding $40 \%$ (Fig. 4). Median time to extinction for $5 \%$ poaching across subpopulations was just 24 yr. Further poaching models showed that as little as $2 \%$ offtake per year, when combined with catastrophic hunting episodes, resulted in major population declines and extinction for all subpopulations except Central (not shown). However, when hunting was stopped after $50 \mathrm{yr}$, the Central and Southeast subpopulations could recover but only if further hunting occurred at $1 \%$ per annum or less. Hunting was, as expected, a deterministic force for extinction in the model, and we predicted that it needs to occur at very low levels $(<1 \%$ per annum, if it goes on beyond $50 \mathrm{yr})$. The current rate of harvest on the ground in Sabah, which may be as high as $4 \%$ per annum, is expected to result in the extinction of the
Bornean banteng with 39-96\% global probability (4 and $5 \%$ offtake).

\subsection{Additional modelling}

Fig. 5 shows the consequences of the management strategy, translocation of individuals from a captivebred population. Given that the population would be founded by just 20 individuals (3 males and 17 females in 3 groups), it is important to include the possibility of inbreeding depression, and it is clear that ensuring that inbreeding is avoided during captive breeding is paramount if the population is to be productive (probability of extinction 0.58 versus 0.03). In addition, although both translocation strategies can provide individuals for translocation, the strategy that starts to supply individuals at Year 10 
a Revised population model hunting $3 \% 100$ years Sipitang Revised population model hunting $3 \% 100$ years Southeast Revised population model hunting 3\% 100 years Central Revised population model hunting $3 \% 100$ years Northeast

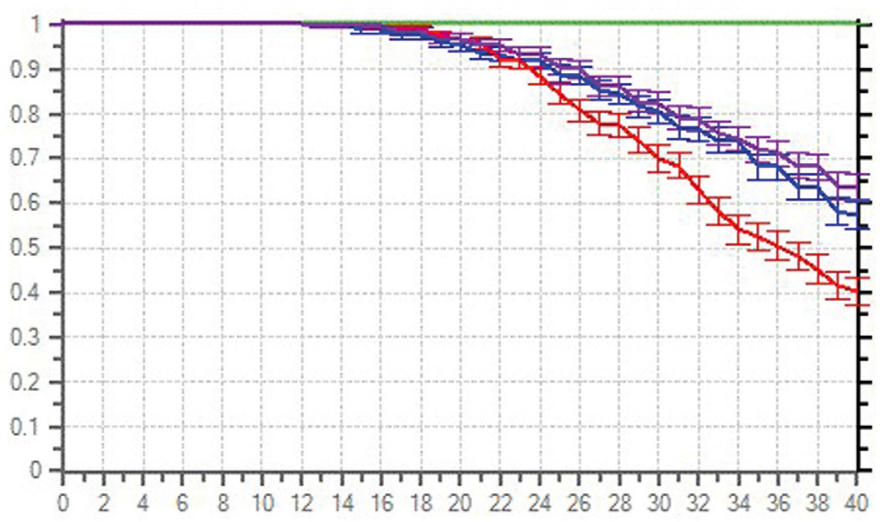

b Revised population model hunting 4\% 100 years Sipitang Revised population model hunting $4 \% 100$ years Southeas Revised population model hunting $4 \% 100$ years Central Revised population model hunting $4 \% 100$ years Northeast

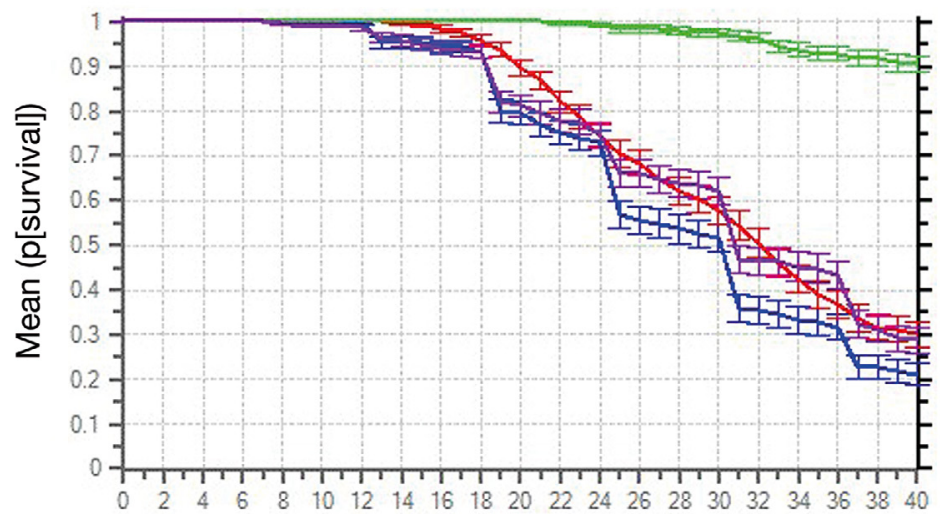

C Revised population model hunting $5 \% 100$ years Sipitang Revised population model hunting $5 \% 100$ years Southeas Revised population model hunting $5 \% 100$ years Central Revised population model hunting $5 \% 100$ years Northeast

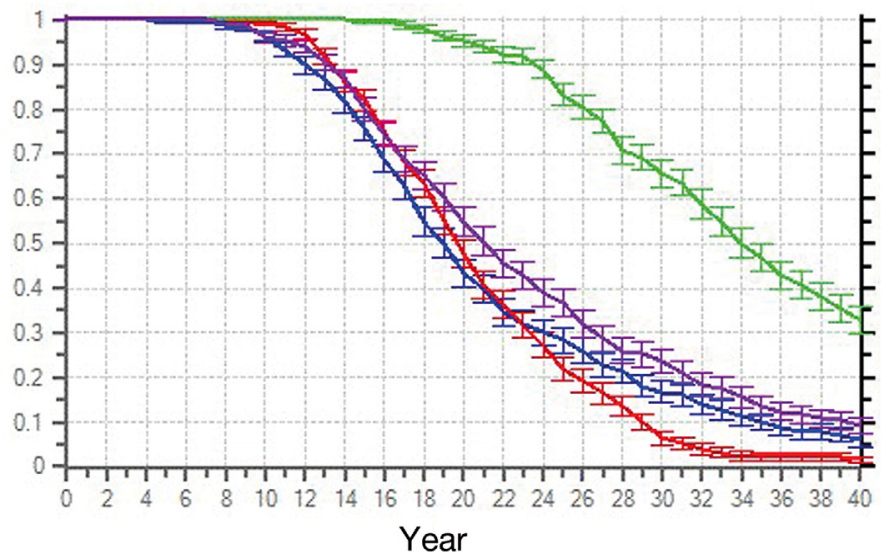

Fig. 4. Probability of Bornean banteng survival $( \pm \mathrm{SE})$ as a function of (a) $3 \%$, (b) $4 \%$ and (c) $5 \%$ annual offtake over a $40 \mathrm{yr}$ period in each of the 4 mangement units identified across the Malaysian state of Sabah. Details are provided in Section 3.3 had a much higher probability of extinction at 0.2 , compared with 0.08 when supplying individuals starting at Year 20. It was also noted that Kulamba and Tabin are currently unconnected, but efforts are underway to reconnect the 2 areas; this may facilitate movement between both populations depending upon the corridor dimensions, security and availability of refuge provided by the vegetative cover. Modelling gene flow between these populations confirmed that connection of these 2 isolated populations under a model including inbreeding depression would more than double the final population size over $100 \mathrm{yr}$ as opposed to keeping them isolated, but that it made very little difference if the reconnection happened at 5, 10 or $20 \mathrm{yr}$ from now.

\section{DISCUSSION}

Our study provides the first extensive compilation of biological parameters from multiple sources for the banteng, and is also the first example of the PHVA approach applied to the Bornean banteng to model population projections in Sabah, and indeed for the banteng per se in any country. The collated parameters may serve as a foundation for modelling the population projections of other wild cattle species in mainland Southeast Asia and Java, and inform models investigating apex predators, such as tigers Panthera tigris and dholes Cuon alpinus. Given the provision of recent field data and information garnered from the consultation process with stakeholders and experts, we delineated 4 management units of bantengs in Sabah: Sipitang (West), Southeast, Northeast and Central. Separate management for these 4 units is advocated, owing to their isolated nature and the absence of connectivity between forests, and the high level of difficulty for bantengs traversing the landscape that is dominated by vast monoculture plantations where they risk persecution (Bajomi \& Takács-Sánta 2011).

From our baseline model, our population growth rate was far lower than that reported by Hone et al. (2010) for feral Bos javanicus in northern Australia, possibly because of greater impacts from deterministic factors such as habitat disturbance, degradation and loss, 


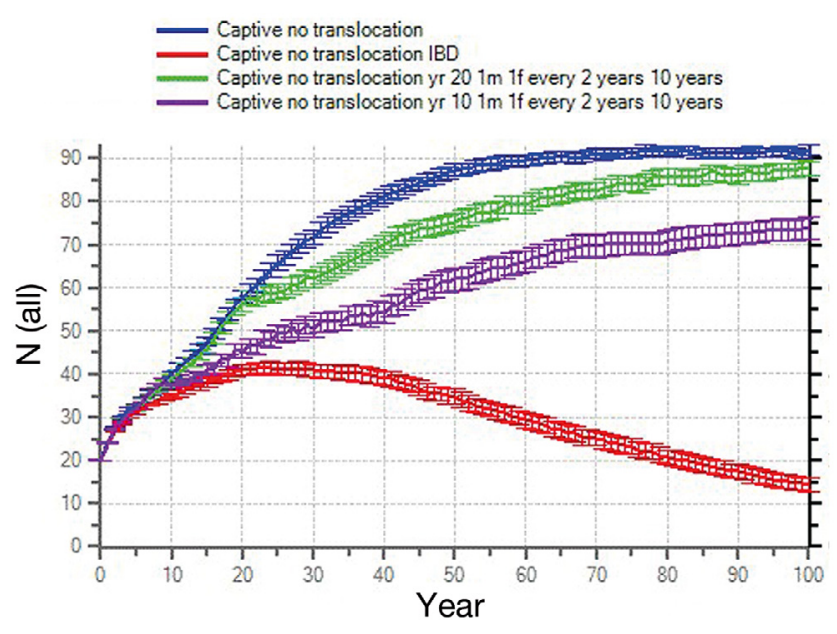

Fig. 5. Effects of exemplar captive management and translocation strategies on viability of captive Bornean banteng in Sabah. Details of the strategies are provided in Sections 2 and 3.4. IBD: inbreeding depression: $\mathrm{m}$ : male; f: female

and over-harvesting (Lacy et al. 2015). The results of our population-based models revealed that the vulnerability of extinction was greatest for the Sipitang and Northeast management units, due to their existing small population size and low annual growth rates that ultimately influenced the long-term declining trend in the population size. Our estimations of the impact of inbreeding are based on default values for vertebrates, however, and the severity of the inbreeding depression varies widely among species (Lacy 2019). B. j. lowi may deviate from these default values; thus it may be safer to assume our results are a best-case scenario for this declining subspecies. With the inclusion of hunting offtake rates, the cessation of population growth for these 2 management units occurred when offtake was low, at only $1 \%$. When systematically increased, population growth ceased for the Southeast unit at $2 \%$, and for the Central unit at $4 \%$. At $5 \%$, the projected time to extinction was very short, with the complete loss of the species occurring in the next 21-39 yr and with the first extinction occurring in Sipitang and the last in the Central unit. The frequency of evidence that has surfaced on social media in recent years, testifying the losses of bantengs from hunting in Sabah, indicates that $5 \%$ offtake is not an unrealistic figure on the ground. Localised extinctions have already occurred in Sabah during the last 3 decades (Melletti \& Burton 2014), and almost certainly within Kalimantan; hunting trophies confirmed the loss of at least 25 individuals in one area of Kalimantan during the 1990s (Hedges \& Meijaard 1999). Observations of the species in Kalimantan are now few, with only a handful of photographic captures on camera traps between 2012 and 2013 (P. Gardner pers. obs.). Without further regulation and control, the loss of individuals from hunting will drive the demise of the species quicker than any other factor modelled.

Despite the overall small population size of bantengs in Sabah, we found that inbreeding depression was an extinction risk for only the 2 smallest and most geographically isolated units in the West (Sipitang) and Northeast of Sabah. Our estimated time to extinction is comparable with that of the low-density sable antelope Hippotragus niger in Zimbabwe (Capon et al. 2013), which was predicted to decline at a rate of $16.7 \%$ per annum, with extinction occurring after $18 \mathrm{yr}$, but this was dependent on the observed baseline rates over a 5 yr period (2000-2005). During this time, the population decline was driven by frequent losses of juveniles by lion predation and not, like in our study, through poaching. Supplementing the population with 30 individuals slowed the decline marginally over the forecasted $100 \mathrm{yr}$ however, the most impactful risk mitigation measure was thought to be effective management of predator populations (Capon et al. 2013). A similar study that evaluated the effect of different management intervention scenarios on the declining Baird's tapir Tapirus bairdii in Honduras found that the current hunting levels would result in extinction in the next $100 \mathrm{yr}$ (McCann et al. 2012). Reducing Baird's tapir offtake rates and frequency (to 1 adult per gender every 3 yr) resulted in a population with positive growth over $100 \mathrm{yr}$ even if the initial population was reduced to $\sim 20$ individuals (McCann et al. 2012). This was an optimal interim strategy, which would allow time to establish recruitment mechanisms (McCann et al. 2012).

A captive breeding programme using 20 wildcaught founder individuals, primarily from the Northeast unit (due to the small and isolated population in this location with the lowest carrying capacity), resulted in inbreeding depression and a decline in the captive population after $40 \mathrm{yr}$ if no individuals were translocated to the wild. Translocation of individuals into the wild after $20 \mathrm{yr}$ of captive breeding had a lower extinction probability than the 10 yr plan (Sabah Wildlife Department 2019); this prolonged strategy would result in a quicker recovery of the population and would be a more effective use of biological and financial resources. With no drastic management intervention to stem the loss of individuals in the $20 \mathrm{yr}$ interim of captive breeding, extinctions would certainly be occurring within the management units and could negate the effort of translocations. More stringent and effective anti-poaching measures 
and enforcement of legislation are therefore fundamental to the survival of bantengs in the wild over the next 2 decades.

The severe habitat fragmentation and clearance for oil palms present severe movement barriers for bantengs, especially in the Northeast and, to a lesser extent, in the West (Bajomi \& Takács-Sánta 2011). As such, dispersal of bantengs in these units to exchange gametes and maintain or increase genetic diversity is improbable. Coupled with intensive poaching using firearms within and around the management units and the injuries sustained by bantengs from snares (Gardner et al. 2019), the long-term viability of these herds is of utmost concern. At present, translocation of individuals into these management units in order to bolster the genetic pool would not be an effective strategy given the unsecure nature of the reserves and the probability of eradication by poachers. No intervention, however, is not an option; given the advancing population decline, conservation of all individuals is required to retain genetic diversity within the population and the effective population size. Indiscriminate rescue-capture of some or all individuals from the Northeast unit for the establishment of a captive breeding programme may be a more productive strategy, thus ensuring conservation of individuals and their genetic diversity against further catastrophic environmental events including fires, which have decimated banteng forest habitat in the northeast (P. Gardner pers. obs.). Indiscriminate rescue-capture would be a blind process without prior knowledge of the genetic variation among the captured individuals, as obtaining high-quality DNA has not been possible to date; therefore, correct management of breeding pairs and their genetic diversity would be integral to minimising inbreeding depression within a captive setting. Low genetic variability is currently an issue for captive-bred Malayan gaur B. gaurus hubbacki in Peninsular Malaysia, as the programme commenced with few founder individuals and has resulted in multiple progeny with shared parents, and this now affects the survival rate of newborn calves (Rosli et al. 2016, Md-Zain et al. 2019). Avoiding total reliance on few founder individuals is paramount, as unforeseen biological complications like unviability could confound reproduction; in situ captive breeding of the Sumatran rhinoceros Dicerorhinus sumatrensis in Sabah suffered a devastating catastrophe following the recent death of the last remaining wild-caught rhino due to uterine tumours (Gokkon 2019). More than one in situ breeding facility supplied with multiple wild-caught individuals originating from different management units would be preferable in Sabah, not least to minimise mortality arising from disease transmission but to maintain wildlife security and avoid unintentional reintroduction, like that of an escaped captive-bred banteng in Thailand (Chaiyarat et al. 2017). Accidental release in Sabah is a real possibility, considering the extensive damage caused by Bornean elephants Elephas maximus borneensis to a banteng forest enclosure in 2012-2013 (P. Gardner pers. obs.) and measures should also be taken to prevent such damage.

Acknowledgements. We thank the Asian Wild Cattle Specialist Group, Chester Zoo, Copenhagen Zoo and San Diego Zoo; and Peter Riger, Steve Mezler, Jamie Ivy, Tim Rowlands, Johanna Rode-Margono, Amy Treanor, John Abernathy, James Burton and Carl Traeholt for their support. We also thank the Sabah Wildlife Department, Sabah Forestry Department and Sabah Biodiversity Centre for allowing us to carry out research in Sabah. This study was funded by the Houston Zoo, Malaysian Palm Oil Council, Woodland Park Zoo, Mohammed bin Zayed Species Conservation Fund and Sime Darby Foundation.

\section{LITERATURE CITED}

Aubert M, Setiawan P, Oktaviana AA, Brumm A and others (2018) Palaeolithic cave art in Borneo. Nature 564: 254-257

* Bajomi B, Takács-Sánta A (2011) Generalizations in the reintroduction literature: a reply to Armstrong \& Seddon. Oryx 45:19

Bennett EL, Nyaoi AJ, Sompud J (2000) Saving Borneo's bacon: the sustainability of hunting in Sarawak and Sabah. In: Robinson JG, Bennett EL (eds) Hunting for sustainability in tropical forests. Cambridge University Press, Cambridge, p 305-324

Boonratana R (1997) A state-wide survey to estimate the distribution and density of the Sumatran rhinoceros, elephant and banteng in Sabah, Malaysia. PhD thesis, Mahidol University, Bangkok

*Badshaw CJ, Isagi Y, Kaneko S, Bowman DMJS, Brook BW (2006) Conservation value of non-native banteng in northern Australia. Conserv Biol 20:1306-1311

Bradshaw CJ, Isagi Y, Kaneko S, Brook BW, Bowman DMJS, Frankham R (2007) Low genetic diversity in the bottlenecked population of endangered non-native banteng in northern Australia. Mol Ecol 16:2998-3008

Capon SD, Leslie AJ, Clegg B (2013) The use of population viability analysis to identify possible factors contributing to the decline of a rare ungulate population in southeastern Zimbabwe. Koedoe 55:1081

Chaiyarat R, Saengpong S, Tunwattana W, Dunriddach P (2017) Habitat and food utilization by banteng (Bos javanicus d'Alton, 1823) accidentally introduced into the Khao Khieo-Khao Chomphu Wildlife Sanctuary, Thailand. Mammalia 82:23-34

Chazine JM (2005) Rock art, burials, and habitations: caves in East Kalimantan. Asian Perspect 44:219-230

* Choquent D (1993) Growth, body condition and demography of wild banteng (Bos javanicus) on Cobourg Peninsula, northern Australia. J Zool 231:533-542 
Davies G, Payne J (1982) A faunal survey of Sabah. IUCN/ WWF Project No. 1692. World Wildlife Fund Malaysia, Kuala Lumpur

* Dobson ADM, Milner-Gulland EJ, Ingram DJ, Keane A (2019) A framework for assessing impacts of wild meat hunting practices in the Tropics. Hum Ecol 47:449-464

*Gardner PC, Hedges S, Pudyatmoko S (2016) Bos javanicus. The IUCN Red List of Threatened Species 2016: e.T2888A46362970. https://dx.doi.org/10.2305/IUCN.UK. 2016-2.RLTS.T2888A46362970.en

Gardner PC, Vaughan I, Liew L, Goossens B (2019) Using natural marks in a spatially explicit capture-recapture framework to estimate preliminary population density of cryptic endangered wild cattle in Borneo. Glob Ecol Conserv 20:e00748

Gokkon B (2019) Malaysia's last Sumatran rhino dies, leaving Indonesia as the final refuge. Mongabay. https://news. mongabay.com/2019/11/malaysias-last-sumatran-rhinodies-leaving-indonesia-as-the-final-refuge/ (accessed 27 November 2019)

Gray TNE (2012) Studying large mammals with imperfect detection: status and habitat preferences of wild cattle and large carnivores in eastern Cambodia. Biotropica 44: 531-536

Gray TNE, Phan C (2011) Habitat preferences and activity patterns of the larger mammal community in Phnom Prich Wildlife Sanctuary, Cambodia. Raffles Bull Zool 59: 311-318

Gray TNE, Phan C, Pin C, Prum S (2011) Establishing baseline ungulate densities in Mondulkiri Protected Forest and Phnom Prich Wildlife Sanctuary. WWF-Cambodia. https://wwfint.awsassets.panda.org/downloads/gray_et_ al_monitoring_ungulates_epl_final.pdf

Gray TNE, Prum S, Pin C, Phan C (2012) Distance sampling reveals Cambodia's Eastern Plains landscape supports the largest global population of the Endangered banteng Bos javanicus. Oryx 46:563-566

Harrison RD, Sreekar R, Brodie JF, Brook S and others (2016) Impacts of hunting on tropical forests in Southeast Asia. Conserv Biol 30:972-981

Hedges S, Meijaard E (1999) Reconnaissance survey for banteng (Bos javanicus) and banteng survey methods training project, Kayan-Mentarang National Park, East Kalimantan, Indonesia. World Wide Fund for NatureIndonesia (WWF) and Centre for International Forestry Research (CIFOR)

*Hone J, Duncan RP, Forsyth DM (2010) Estimates of maximum annual population growth rates $\left(r_{\mathrm{m}}\right)$ of mammals and their application in wildlife management. J Appl Ecol 47:507-514

IUCN-SSC Asian Wild Cattle Specialist Group (2010) Regional conservation strategy for wild cattle and buffaloes in South-east Asia. IUCN-SSC AWCSG, Oxford

Kleinschroth F, Healey JR (2017) Impacts of logging roads on tropical forests. Biotropica 49:620-635

Lacy RC (2019) Lessons from 30 years of population viability analysis of wildlife populations. Zoo Biol 38:67-77

Lacy RC, Pollak JP (2017) Vortex: a stochastic simulation for the extinction process. Version 10.2.6. Chicago Zoological Society, Brookfield, IL

Lacy RC, Miller PS, Traylor-Holzer K (2015) An overview of

Editorial responsibility: Nils Bunnefeld,

Stirling, UK

Reviewed by: 2 anonymous referees population viability analysis using VORTEX. Vortex 10 User's Manual. 19 January 2015 Update. IUCN SSC Conservation Breeding Specialist Group, Chicago Zoological Society, Apple Valley, MN

Lim HY, Gardner PC, Abram NK, Yusah KM, Goossens B (2021) Identifying habitat and understanding movement resistance for the Endangered Bornean banteng Bos javanicus lowi in Sabah, Malaysia. Oryx 55:122-130

* McCann NP, Wheeler PM, Coles T, Bruford MW (2012) Rapid ongoing decline of Baird's tapir in Cusuco National Park, Honduras. Integr Zool 7:420-428

*Md-Zain BM, Abdul-Aziz A, Aifat NR, Mohd-Yusof NS and others (2019) Sequence variation data of the mitochondrial DNA D-loop region of the captive Malayan gaur (Bos gaurus hubbacki). Data Brief 24:103532

Melletti M, Burton J (eds) (2014) Ecology, evolution and behaviour of wild cattle: implications for conservation. Cambridge University Press, Cambridge

Olsen MM (2002) The banteng in Sabah: habitat, distribution and conservation. Tech Assist Rep 32. University of Copenhagen and Danish Cooperation for Environment and Development, Copenhagen

Olsen MM (2003) Habitat and diet selection in banteng (Bos javanicus) on Borneo. Dissertation, University of Copenhagen

Pin C, Ngoprasert D, Gray TNE, Savini T, Crouthers R, Gale GA (2020) Utilization of waterholes by globally threatened species in deciduous dipterocarp forest of the Eastern Plains landscape of Cambodia. Oryx 54:572-582

* Pudyatmoko S $(2017)$ Free-ranging livestock influence species richness, occupancy, and daily behaviour of wild mammalian species in Baluran National Park, Indonesia. Mamm Biol 86:33-41

Pudyatmoko S, Djuwantoko (2006) Sex ratio, herd size and composition and sexual segregation in banteng in the Baluran National Park, Indonesia. J Biol Sci 6: 370-374

Rosli N, Ithnin H, Rovie-Ryan JJ (2016) Inbreeding depression of captive Malayan gaur (Bos gaurus hubbacki) at Jenderak Selatan Wildlife Conservation Centre, Pahang. J Wildl Parks 31:71-79

Rutter O (1922) British North Borneo: an account of its history, resources, and native tribes. Butler \& Tanner, London

Sabah Wildlife Department (2019) Bornean Banteng Action Plan for Sabah 2019-2028. Sabah Wildlife Department, Kota Kinabalu

Sarda J (2016) Depending on Sabah for $80 \%$ of supplies. Daily Express, Sabah

* Sario R (2015) Tighter access to forest reserves. Daily Express. http://www.dailyexpress.com.my/news.cfm?News $\mathrm{ID}=96670$

* Steinmetz R, Chutipong W, Seuaturien N, Chirngsaard E, Khaengkhetkarn M (2010) Population recovery patterns of Southeast Asian ungulates after poaching. Biol Conserv 143:42-51

Tilker A, Abrams JF, Mohamed A, Nguyen A and others (2019) Habitat degradation and indiscriminate hunting differentially impact faunal communities in the Southeast Asian tropical biodiversity hotspot. Commun Biol 2: 396

Submitted: May 22, 2020

Accepted: January 6, 2021

Proofs received from author(s): July 2, 2021 